\title{
The typologically rare approximant inventory of Kajkwakhrattxi: A series of natural sound changes
}

\author{
Teela Huff \& Myriam Lapierre*
}

\begin{abstract}
Kajkwakhrattxi, a Northern Jê language spoken by fewer than 30 elders in Mato Grosso, Brazil, exhibits a typologically rare sound inventory, especially with respect to its series of approximants: $/ \mathrm{w}, \tilde{\mathrm{w}}, \mathrm{M}, \mathfrak{r}, \tilde{\mathfrak{l}}, \mathrm{j} /$, realized as a total of $17 \mathrm{dif}-$

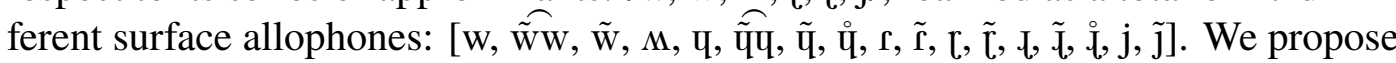
a novel reconstruction of Proto-Northern-Jê that accounts for this unusually dense inventory of approximants, namely as the result of a series of natural sound changes involving processes of lenition and assimilation. Our analysis makes use of novel fieldwork data on three underdocumented and endangered languages of the family: Kajkwakhrattxi, Panãra, and Kayapô. As a result, our reconstruction is based on a more phonetically detailed and internally coherent data set than was available to previous comparative work on Jê languages. Our results provide evidence for the possible breadth of diversity in the phonological systems of natural languages, both synchronically and diachronically, and advances our knowledge of the sound changes that occurred from Proto-Northern-Jê to its daughter languages.
\end{abstract}

Keywords. sound change; historical reconstruction; approximants; Northern Jê; Kajkwakhrattxi

\section{Background.}

\subsection{KaJKWAKHRATTXI.}

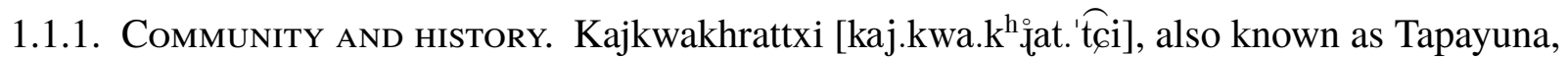
is a Jê language spoken by fewer than 30 elders in Mato Grosso, Brazil. Located inside the CapotoJarina Indigenous Land, Kamwêrêtxikô is the only ethnically Kajkwakhrattxi village (population $\simeq 150$ ), and most Kajkwakhrattxi are not native speakers of the language. The current language endangerment situation is a direct consequence of violent contact between local Brazilian farmers and Kajkwakhrattxi, which occurred in the 1950s and 60s. The population dropped from an estimated 400-1200 individuals to only 41. Kajkwakhrattxi survivors of the attack were forced off of their land and relocated to a Kĩsêdjê community in 1970 (de Aquino 1970). Although Kĩsêdjê is a very closely related Jê group both in cultural and linguistic terms, the two groups identify as distinct nations. In 1988, a conflict between the two groups forced the Kajkwakhrattxi to seek refuge among the Kayapô, a more distantly related Jê group. This new coresidence lasted until 2009, when the village of Kamwêrêtxikô was founded (Lima 2019).

Although the Kajkwakhrattxi community now lives as an independent nation in their own village, they face serious and immediate threats to their language and culture, as a result of having lived fifty years as a minority group. The vast majority of the inhabitants of Kamwêrêtxikô were born and grew up in a non-Kajkwakhrattxi community, and the language is no longer used

\footnotetext{
* This work would would not have been possible without the following individuals: All members of the Panãra and Kajkwakhrattxi communities, and Nokere Tapayuna, Sôpôa Panãra, and Kunityk Mẽtyktire-Panãra in particular; Jérémie Beauchamp, and João Paulo Denófrio. We would also like to thank the following people for helpful feedback at various stages of this work: Andrew Garrett, Larry Hyman, Lev Michael, Zachary O’Hagan, Clara Fortes Brandão, Christine Beier, and Katie Russell. Authors: Teela Huff, University of California, Berkeley (thuff@berkeley.edu) \& Myriam Lapierre, University of California, Berkeley (myriam.lapierre@berkeley.edu).
} 
for most daily interactions. Members of the Kajkwakhrattxi population over the age of approximately 50 grew up in a Kĩsêdjê speaking village, and are thus native speakers of Kĩsêdjê. Members of the population below the age of 50 grew up in a Kayapô speaking village, and are native speakers of Kayapô. Since both Kĩsêdjê and Kayapô are closely related languages, code switching and calquing are frequently observed. In fact, these phenomena are so widespread that younger speakers of Kajkwakhrattxi are often unaware of their language mixing and are at times unsure of the source language of a given word. That said, the use of spoken Kajkwakhrattxi in the village holds high social prestige, and the community is actively involved in trying to revive the use of the language in several spheres of life.

1.1.2. Sound InVEntory. Kajkwakhrattxi exhibits a typologically unusual sound inventory, with a total of 14 consonants and 17 vowels. Both consonants and vowels exhibit a contrast in nasality (Beauchamp 2019). As seen in Table 1, the language also presents a particularly dense inventory of approximants. There exist six distinct phonemic approximant categories: / $, \tilde{w}, \mu, \mathfrak{r}$,

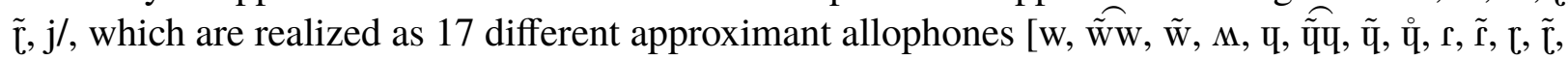
f, $\tilde{\mathrm{l}}, \stackrel{\imath}{\mathrm{l}} \mathrm{j}, \tilde{\mathrm{j}}]$.

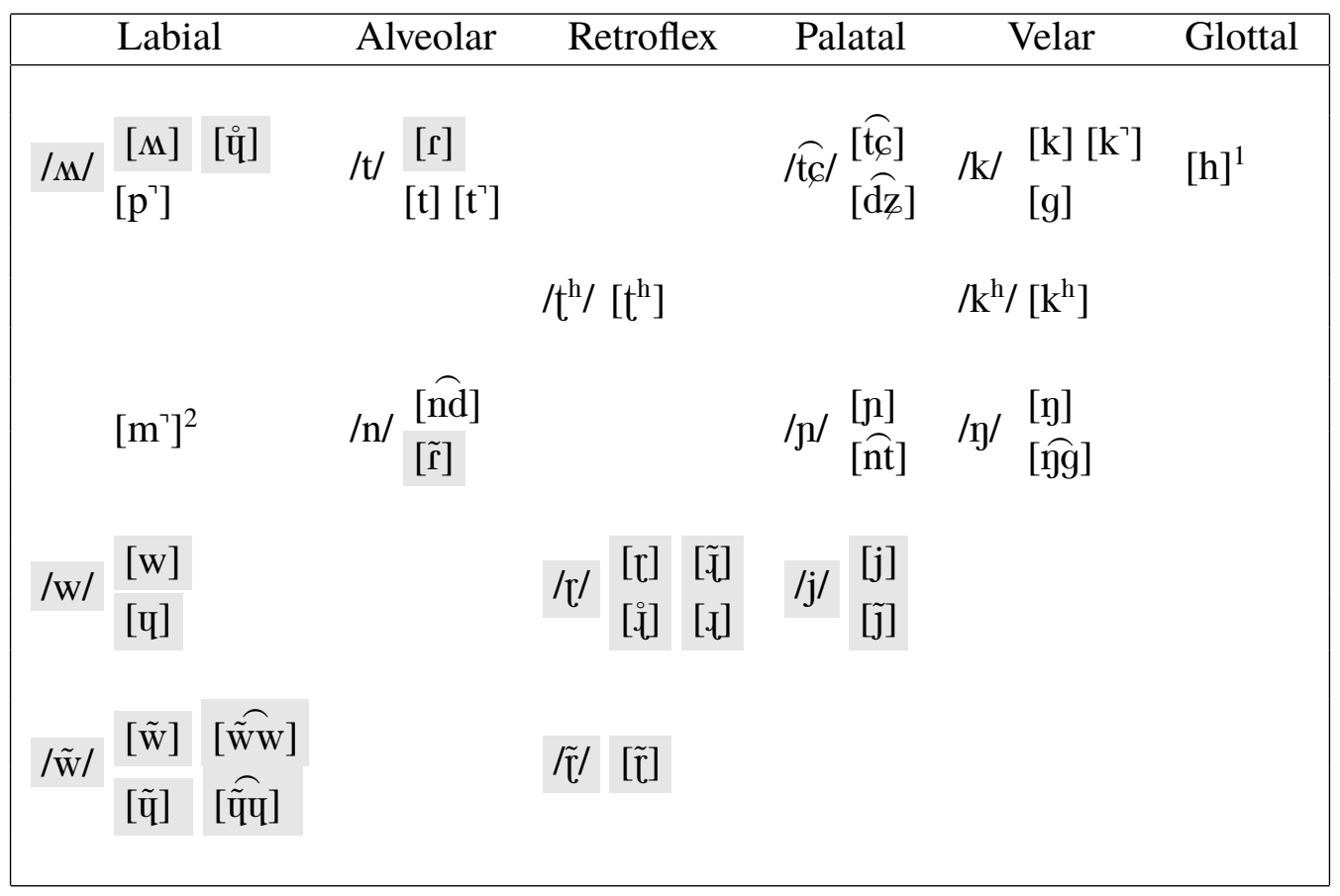

Table 1. Kajkwakhrattxi consonant inventory. Phonemes appears in slashes, and all surface al-lophones appear in square brackets to the right of the relevant phoneme. All approximants are highlighted in gray.

\footnotetext{
${ }^{1}$ The fricative $[\mathrm{h}]$ occurs as an allophone of voiceless $/ \mathrm{M} /$ when preceding the approximant $[\mathrm{r}]$ as well as when preceding the vowels $[\partial, \mathrm{u}, \mathrm{o}, \mathrm{\jmath}, \tilde{\mathrm{o}}, \tilde{\mathrm{u}}]$.

${ }^{2}$ The unreleased bilabial nasal [m?] is rare in the Kajkwakhrattxi lexicon and only occurs as an allophone of / $\tilde{w} /$ in syllable coda position when immediately preceding another consonant.
} 


\begin{tabular}{|ccc|}
\hline $\mathrm{i}$ & $\mathrm{uI}$ & $\mathrm{u}$ \\
$\mathrm{e}$ & $\partial$ & $\mathrm{o}$ \\
$\varepsilon$ & $\Lambda$ & $\mathrm{J}$ \\
& $\mathrm{a}$ & \\
\hline
\end{tabular}

Table 2a: Oral vowels

\begin{tabular}{|ccc|}
\hline$\tilde{\mathbf{1}}$ & $\tilde{\mathrm{u}}$ & $\tilde{\mathrm{u}}$ \\
$\tilde{\mathrm{e}}$ & $\tilde{\Lambda}$ & $\tilde{\mathrm{o}}$ \\
& $\tilde{\mathrm{a}}$ & \\
\hline
\end{tabular}

Table 2b: Nasal vowels

Notably, both the labial approximants /w, w/ and the retroflex approximants $/ \mathrm{r}, \tilde{\mathrm{f}} /$ exhibit a contrast in nasality, as evidenced by the minimal pairs in (1) and (2) respectively.
a. /wa/ [wa] '1.Nom'
b. / $\tilde{\mathrm{w} a} / \tilde{\tilde{\mathrm{w}} \mathrm{wa}}]$ 'liver'
(2) a. /ru/
[ru] 'long'
b. $/ \tilde{\tilde{\tau}} \mathrm{w} / \tilde{\tilde{r}} \mathrm{w}] \quad$ 'animal'

The nasalized labial approximant / $\tilde{\mathrm{W}} /$ is realized as post-oralized $[\tilde{\mathrm{W}} \mathrm{W}, \widetilde{\tilde{\mathrm{U}}}]$ before contrastively oral vowels. The remaining labial phonemes are voiced $/ \mathrm{w} /$ and voiceless $/ \mathrm{m} /$, whose particular voicing contrast is attested in only three other languages (Blevins 2004; p. 29-30). From three

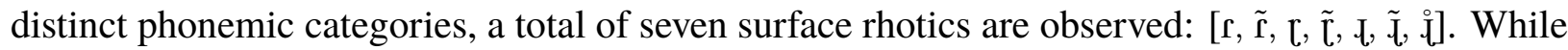
each of these phonological properties is of interest in its own right, their co-occurrence in the sound system of a single language is particularly unexpected. The goal of this article is to propose a novel reconstruction of Proto-Northern-Jê that accounts for the unusually dense inventory of approximants currently observed in Kajkwakhrattxi. We argue that this results from a series of natural sounds changes involving lenition and assimilation.

1.2. The Jê Language family. Figure 1 presents the internal organization of the Jê language family according to Nikulin's (2020) recent proposal. Following this analysis, Kajkwakhrattxi is a member of the Northern branch, a subgroup of the larger Goyaz Jê branch. Also contained within this branch are Apinajé, Kĩsêdjê, and Timbira, as well as two additional languages on which our reconstruction is crucially based: Panãra and Kayapô. The most closely related sister language of Kajkwakhrattxi is Kĩsêdjê. Kajkwakhrattxi and Kĩsêdjê are mutually intelligible, and the two languages are often jointly referred to under the label of Suyá. For this reason, they share the same ISO code [suy], despite the fact that the two languages have clearly distinct grammars in both the phonological and morphosyntactic domains, and that they are recognized as distinct varieties by speakers of both languages.

Nikulin (2020) proposes several sound changes involving Proto-Northern-Jê (PNJ) that are relevant to the approximants of Kajkwakhrattxi. In onset position, the author reconstructs PNJ ${ }^{*} p>M$ in Proto-Suyá. Following this change, PNJ *b $>$ *p in Proto-Suyá, reintroducing *p to the inventory, which then underwent the change * $\mathrm{p}>\mathrm{w}$ in Kajkwakhrattxi. A similar change is proposed for the bilabial nasals in onset position, whereby PNJ *m(b) $>\tilde{w}, *^{*} \mathrm{~m}(\mathrm{~b}) \mathrm{r}>\tilde{\mathrm{r}}$, and $* \mathrm{mbj}>\mathrm{j}$ in Kajkwakhrattxi. The author further proposes a sound change, whereby PNJ *n in coda position became [j]. While some of these proposed sound changes are in line with our own proposal, our phonological reconstruction departs from Nikulin's analysis in some significant ways, as laid out in $\S 3$. 


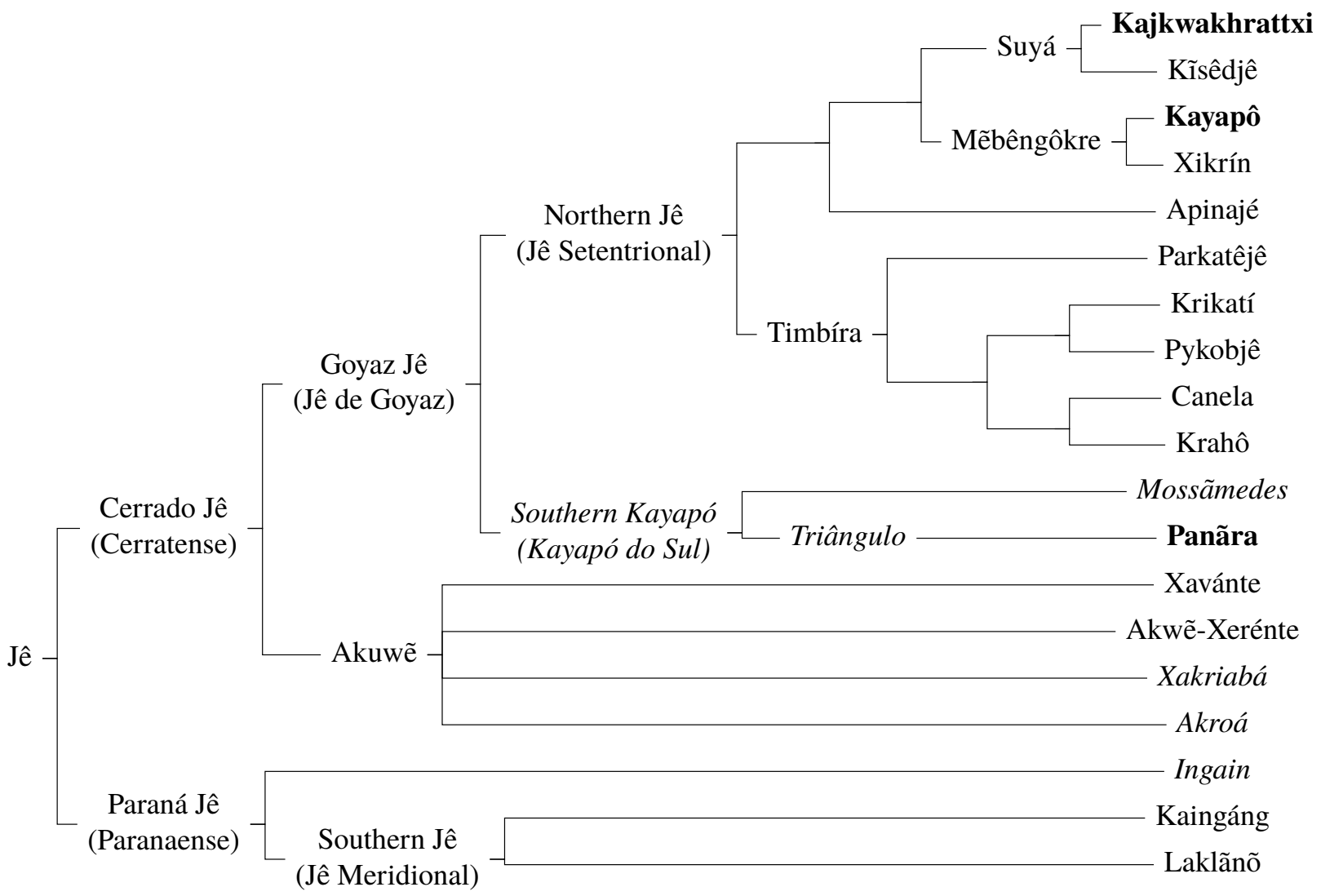

Figure 1. Internal organization of the Jê family, adapted from (Nikulin 2020)

2. Methodology. The second author collected first-hand broad phonemic and detailed phonetic transcriptions of a 350 word Swadesh list for three Northern Jê languages: Kajkwakhrattxi [ISO: suy-tap], Panãra [ISO: kre], and Kayapô [ISO: txu]. The Panãra data was collected with Sôpôa Panãra in the village of Nãnsêpotiti in 2018 (Lapierre et al. 2020); the Kajkwakhrattxi data was collected with Nokêrê Tapayuna and Jérémie Beauchamp in the village of Kamwêrêtxiko in 2018 (Beauchamp et al. 2020); and the Kayapô data was collected with Kunityk Mẽtyktire-Panãra and João Paulo Denófrio in the village of Nãnsêpotiti in 2019. With the use of this novel data, our reconstruction (Lapierre \& Huff ms.) makes use of a more phonetically detailed dataset than was possible for previous historical analyses of Jê languages (Davis 1966; Lapierre et al. 2016; Nikulin 2020). Because our data for Kajkwakhrattxi, Panãra, and Kayapô was transcribed by the same trained phonetician, our dataset is more internally coherent, making the comparison of data across languages maximally transparent. In particular, prior comparative work for Jê is based on very limited data for both Kajkwakhrattxi and Panãra, which are the two most undedescribed and divergent languages of the family.

This first-hand data was supplemented with lexical items from published sources on the other three Northern-Jê languages, namely Apinajé [ISO: apn] (Oliveira 2005), Kĩsêdjê [ISO: suy] (Santos 1997; Rodrigues \& Ferreira-Silva 2011; Nonato 2014, p.c. 2016), and Timbira [ISO: ram] (Popjes \& Popjes 1986; Souza 2011; Alves 2004; Amado 2004; Miranda 2010; Silva 2011). Using cognate sets of Jê-specific roots, we followed the comparative method to reconstruct PNJ 
forms and corresponding sound changes. In the following section, we describe the set of specific sound changes that gave rise to Kajkwakhrattxi's synchronic inventory of approximants.

\section{Proposal.}

3.1. Proposed reconstructed inventory. Table 3 presents our proposed reconstruction of Proto-Northern-Jê's consonant inventory. PNJ's consonant inventory is notably less marked than that of Kajkwakhrattxi, having only three distinct approximant categories /w, $\mathrm{c}, \mathrm{j} /$, realized as four allophones: [w, u, r, j]. Unlike in the case of Kajkwakhrattxi, PNJ's approximants do not contrast in nasality.

\begin{tabular}{|c|c|c|c|}
\hline Labial & Alveolar & Palatal & Velar \\
\hline $\begin{array}{ll}/ \mathrm{p} / \quad & [\mathrm{p}][\mathrm{p}\urcorner] \\
& {[\mathrm{b}]}\end{array}$ & $\begin{array}{ll}/ \mathrm{t} / & {[\mathrm{t}]\left[\mathrm{t}^{\urcorner}\right]} \\
& {[\mathrm{d}]}\end{array}$ & $\stackrel{\mathrm{t} f}{ } / \stackrel{[\mathrm{t} f]}{\left[\widetilde{\mathrm{d}_{3}}\right]}$ & $/ \mathrm{k} / \frac{[\mathrm{k}]\left[\mathrm{k}^{\urcorner}\right]}{[\mathrm{g}]}$ \\
\hline$/ \mathrm{m} / \underset{[\mathrm{mb}]}{[\mathrm{m}]\left[\mathrm{m}^{\urcorner}\right]}$ & $\begin{array}{c}/ \mathrm{n} /{ }^{3}{ }_{[\widetilde{\mathrm{nd}}]}^{\left[\mathrm{n}^{\urcorner}\right]} \\
\end{array}$ & $/ \mathrm{p} / \underset{[\mathrm{n}]\left[\mathrm{p}^{\urcorner}\right]}{\left[\mathrm{nd}_{3}\right]}$ & $/ \mathrm{y} / \stackrel{[\mathrm{y}]}{[\hat{\mathrm{yg}}]}$ \\
\hline $\begin{array}{ll}{[\mathrm{w}]} \\
{[\mathrm{y}]}\end{array}$ & $/ \mathrm{f} / \quad[\mathrm{c}]$ & $/ \mathrm{j} / \quad[\mathrm{j}]$ & \\
\hline
\end{tabular}

Table 3. Proposed Reconstruction for PNJ Consonant Inventory

While a full summary of the morphophonology of PNJ is beyond the scope of this article, we note here a few typological characteristics of the language which are relevant to the reconstruction proposed here. First, PNJ exhibits a full inventory of contrastively nasal vowels, as is the case in all of its extant daughter languages. Second, the vast majority of morphemes in PNJ are monosyllabic, and compounding is very frequent. Third, the syllable template is $(\mathrm{C})(\mathrm{C})(\mathrm{C}) \mathrm{V}(\mathrm{C})$, where syllables with triconsonantal onsets are exceedingly rare and limited to $/ \mathrm{krw} /$, and codas are only observed in morpheme-final position. We reconstruct a process of word-final copy vowel epenthesis for words ending with an underlying oral obstruent or approximant $\left(\emptyset \rightarrow\left[\mathrm{V}_{i}\right] /\right.$ $\left.\mathrm{V}_{i} \mathrm{C} \#\right)$, as well as a process of intervocalic voicing of obstruents occurring in the onset of unstressed syllables $\left(/ \mathrm{T} / \rightarrow[\mathrm{D}] / \mathrm{V} \_\mathrm{V}\right)$. Furthermore, nasal consonants are post-oralized when they occur before a phonemically oral vowel $\left(/ \mathrm{N} / \rightarrow[\widehat{\mathrm{ND}}] /{ }_{-} \mathrm{V}\right)$. And finally, the labio-velar approximant is palatalized before front vowels $(/ \mathrm{w} / \rightarrow[\mathrm{u}] /$ _ front $\mathrm{V})$.

In the following subsections, we propose a series of sound changes from PNJ to account for Kajkwakhrattxi's unusual approximant inventory. These changes are all instances of lenition or assimilation, which specifically involve retroflexion (§3.2), flapping (§3.3), fusion (§3.4), and gliding $(\$ 3.5)$.

\footnotetext{
${ }^{3}$ Likely as the result of an accidental gap in the lexicon, PNJ's alveolar nasal consonant /n/ only occurs in syllable onset position preceding an oral vowel, or in coda position preceding another consonant. In these positions, /n/ is realized as [ $\widehat{\mathrm{nd}}]$ and $\left[\mathrm{n}^{\urcorner}\right]$respectively. As such, the fully nasalized allophone [n], which is predicted to occur in the onset of a syllable containing a nasal vowel, is not found in the lexicon.
} 
3.2. Retroflexion. One of the most notable sound changes that occurred in Kajkwakhrattxi after the split with Kĩsêdjê is the unconditioned retroflexion of the coronals *r and *t to [r] and $\left[\mathrm{t}^{\mathrm{h}}\right]^{4}$, respectively (3). The phonemic retroflexed flap $/ \mathrm{r} /$ further underwent an assimilation process, whereby it became a retroflexed glide [^] immediately after a velar consonant. This retroflex

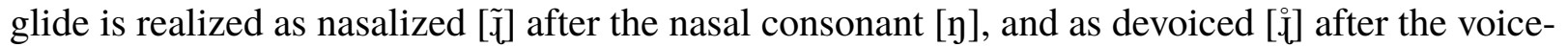
less consonant [k]. These changes are summarized in (4).

(3) $* r, t>r, t^{\mathrm{h}}$

(4) $*_{\tau}>_{\ell} /$ velars

a. $* \mathrm{r}>\mathrm{l} / \mathrm{\textrm {g }}_{-}$

b. $* \tau>\tilde{l} / \eta_{-}$

c. $* \tau>\imath / \mathrm{k}_{-}$

Table 4 presents cognate sets with synchronic forms for Panãra, Kayapô and Kajkwakhrattxi, along with their English gloss and reconstructed PNJ form. As can be seen in the comparative

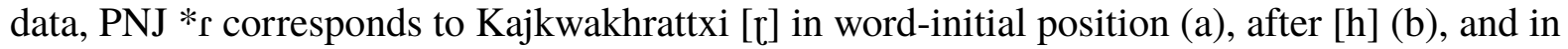

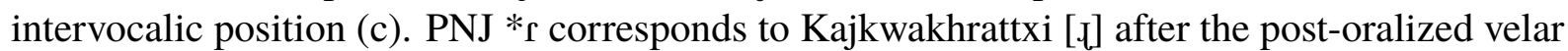

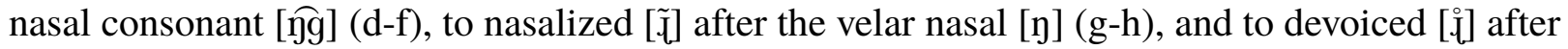
the voiceless velar stop $[\mathrm{k}](\mathrm{i}-\mathrm{k})$.

\begin{tabular}{|c|c|c|c|c|c|c|}
\hline \multicolumn{2}{|r|}{ Gloss } & \multirow{2}{*}{$\frac{\text { PNJ }}{\text { *'øэ.bo }}$} & \multirow{2}{*}{$\frac{\text { Panãra }}{\text { ['j3:.pu] }}$} & \multirow{2}{*}{$\begin{array}{l}\text { Kayapô } \\
{\left[\text { rop }^{\prime}\right]}\end{array}$} & \multicolumn{2}{|c|}{ Kajkwakhrattxi } \\
\hline a. & 'dog, jaguar' & & & & $/$ pow/ & ['กะ.wo] \\
\hline b. & 'path' & *ргu & [рјш] & [ргш] & $/ M[U /$ & [htw] \\
\hline c. & 'termite' & *го.' го & [jo:] & [ro.'rot’] & /roro/ & [ro.'to] \\
\hline d. & 'egg' & *jğre & [ĩ̄.'kre] & 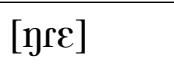 & $/ \lg \mathrm{g} /$ & [jg.te] \\
\hline e. & 'lowland paca' & *ggra & [ij.'kja] & [рга] & /ntatçi/ & 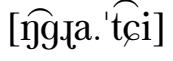 \\
\hline f. & 'dry' & 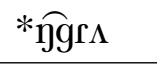 & $\mathrm{n} / \mathrm{a}$ & {$[\mathrm{\eta g} \Lambda]$} & $\operatorname{lng} \Lambda /$ & [ \\
\hline g. & 'tucan' & *yrõ & [nõ.kwe.'kwعр] & [yrõ] & /ytõt & 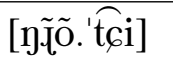 \\
\hline h. & 'yellow' & $* \operatorname{\eta g} \Lambda$ & [si.ko.pa.'kjã] & 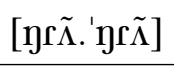 & $/ n[\tilde{\Lambda}][\tilde{\Lambda} /$ & 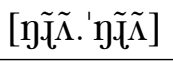 \\
\hline i. & 'cold' & *kru & [kjü] & [kru] & $/ \mathrm{kruw} /$ & [k:luu] \\
\hline 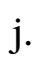 & 'head' & *krẽ & [kjã] & {$[\mathrm{kr} \tilde{\Lambda}]$} & $/ \mathrm{k}[\tilde{\Lambda} /$ & {$[\mathrm{k} \cdot \tilde{\Lambda} \tilde{n}]$} \\
\hline $\mathrm{k}$. & 'fish stun plant' & *a.'kro & [a.'kjo] & [ha.'kro] & /akro/ & [a.'kịo] \\
\hline
\end{tabular}

Table 4. Comparative data for retroflexion

Though retroflexed sounds are rare in Amazonia, and otherwise unattested among Jê languages, the retroflexion of $\mathrm{r}$-colored sounds in in fact very frequent across the world's languages. The sound change $r>\tau$ is attested in Nyawaigi (Hamann 2005), and the sound change $[>\tau$ is attested in Hindi (Bakst 2012). In Cuban Spanish / $\mathrm{r} /$ is retroflexed to [r] in pre-consonantal position (Lipski 2011). Furthermore, the English rhotic /I/ can be articulated with either a bunched

${ }^{4}$ The retroflexion process that occurred in Kajkwakhrattxi from PNJ *t also involves aspiration, resulting in the synchronic form $\left[\mathrm{t}^{\mathrm{h}}\right]$. 
tongue position or a retroflex articulation (Mielke et al. 2016). Processes that involve retroflexion of rhotic consonants can be attributed to an enhancement of F3 lowering, as both rhoticization and retroflexion have an F3 lowering effect.

3.3. Flapping. Following the unconditioned retroflexion of PNJ * ${ }^{2}$ in Kajkwakhrattxi, PNJ's

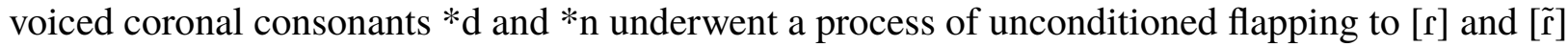
respectively in Kajkwakhrattxi (5).

(5) *voiced coronal > $\mathrm{f}$
a. $* \mathrm{~d}>\mathrm{r}$
b. $* \mathrm{n}>\tilde{\mathbf{c}}$

While this process can be described as unconditioned, it is worth noting that both coronal consonants only occurred in prosodically weak positions in PNJ. Specifically, PNJ *n and *d (along with the other voiced stops, ${ }^{*} \mathrm{~b}$, and $*^{*} \mathrm{~g}$ ) only occurred in morpheme-final position. PNJ $*_{n}$ is unattested in onset position, and word-medial codas are not reconstructible to PNJ. As is the case in several Jê languages (such as Kajkwakhrattxi, Kĩsêdjê, Panãra, and Xavante) word-final oral consonant codas in PNJ triggered two phonological processes: copy vowel epenthesis and unstressed penultimate vowel lengthening. The result of these two processes is that a form such as PNJ /mbut/ 'neck' was realized as ['mbu:.du]. As evidenced by the comparative data in Table 5 (a-c), Kajkwakhrattxi has extended the copy vowel epenthesis process to occur with all morpheme-final codas, including word-final nasal consonants. ${ }^{5}$ As such, while the flapping of $\mathrm{PNJ} * \mathrm{~d}$ and $* \mathrm{n}$ can be described as unconditioned, this lenition process is, in fact, only attested in intervocalic position, in the onset of a word-final unstressed syllable.

The comparative data in Table 5 shows the correspondence of PNJ oral *d between two vow-

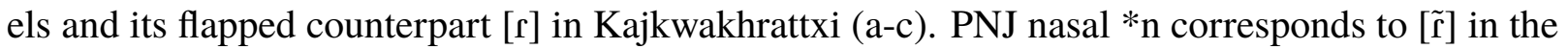
same phonological environment in Kajkwakhrattxi (d-f).

\begin{tabular}{|c|c|c|c|c|c|c|}
\hline & Gloss & PNJ & Panãra & Kayapô & \multicolumn{2}{|c|}{ Kajkwakhrattxi } \\
\hline a. & 'neck' & *'mbur.du & [ĩm.'pur.ti] & {$\left[\mathrm{mut}^{\prime}\right]$} & 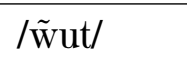 & 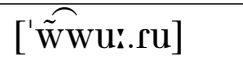 \\
\hline b. & 'brown howler' & *ku.'bui.du & [ip.'pur.ti] & [ku.'but'] & $/ \mathrm{k}^{\mathrm{h}} \mathrm{uwut} /$ & 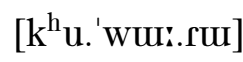 \\
\hline c. & 'tapir' & *ku.'krw:.du & [ik.'kjws.ti] & [ku.'krut'] & /kukrut/ & [ku.'kịu:.гш] \\
\hline d. & 'knee' & *kõn? & [kon] & [kõn’] & $/ \mathrm{k}^{\mathrm{h}} \tilde{\mathrm{on}} /$ & ['kh $\left.{ }^{\mathrm{o}}: \tilde{\mathrm{f}} \tilde{\mathrm{o}}\right]$ \\
\hline 6 & 'stone' & *kẽn? & [kjẽen] & [kẽn?] & $/ \mathrm{k}^{\mathrm{h}} \tilde{\mathrm{e}} /$ & ['khẽẽ..$\tilde{\mathrm{e}}]$ \\
\hline f. & 'gourd' & *ə̧go.'kõn? & $\mathrm{n} / \mathrm{a}$ & [yo.'kon’] & /nok õn/ & [Øgo.'kh õ \\
\hline
\end{tabular}

Table 5. Comparative data for flapping

Flapping of $[\mathrm{d}]$ and $[\mathrm{n}]$ is a very frequent and widely attested process of lenition. For instance, this occurs synchronically in Standard American English, producing the flap [r] in /waId 7 /

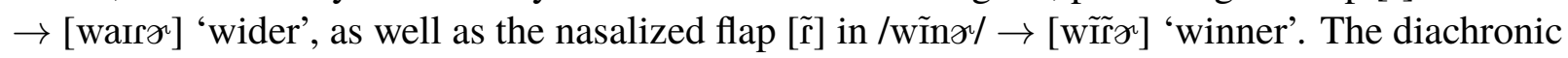
change involving the nasal flap $\mathrm{n}>\tilde{\boldsymbol{r}}(>\mathrm{r})$ is also attested in Tosk Albanian (Albany 2015).

${ }^{5}$ The majority of PNJ's voiced stops $* \mathrm{~b},{ }^{*} \mathrm{~d},{ }^{*} \mathrm{~g}$ are reconstructible to the onset position of a word-final unstressed syllable containing a copy vowel, as in $(5 \mathrm{a}-\mathrm{c})$, where they were allophones of $* \mathrm{p},{ }^{*} \mathrm{t},{ }^{*} \mathrm{k}$ respectively. 
3.4. Fusion. A unique sound change to occur in Northern-Jê is a process of fusion giving rise to a nasalized retroflexed approximant $/ \tilde{\hat{\tau}} /$ in Kajkwakhrattxi. This process happened crucially after Kajkwakhrattxi had split off from Kĩsêdjê, as this change did not affect Suyá. As in (6), the PNJ

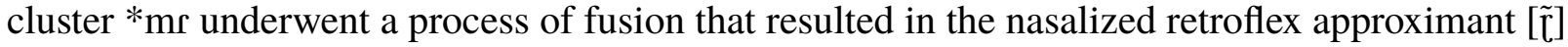
in Kajkwakhrattxi. Given that Kajkwakhrattxi also has a contrastive oral retroflexed approximant $/ \mathrm{r} /(\$ 3.2)$, this process of nasal fusion resulted in a contrast in nasality for the retroflexed approximants $/ \mathfrak{r}, \tilde{\mathrm{r}} /$ in the language.

$$
* m r>(m \tilde{\tilde{l}})>\tilde{\mathfrak{l}}
$$

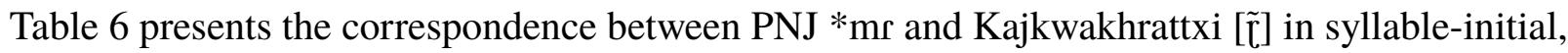
or word-initial position (a-c). Note that it is unclear whether this process of retroflexion happened before or after fusion, as either path would produce the same resulting phones in Kajkwakhrattxi.

\begin{tabular}{|c|c|c|c|c|c|}
\hline & Gloss & PNJ & Panãra & Kayapô & Kajkwakhrattxi \\
\hline a. & 'genipa' & *mro.' $\widehat{t} \int \mathrm{i}$ & [pju.'ti] & [mro.'ti] & 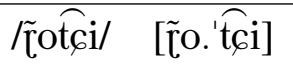 \\
\hline D. & 'ant' & *mrũm? & [pjõn.'swa] & [mrũm?] & $/ \tilde{\tilde{u}} \tilde{u} \tilde{w} /$ \\
\hline c. & 'animal' & *mruा & $\mathrm{n} / \mathrm{a}$ & [mru] & 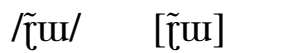 \\
\hline
\end{tabular}

Table 6. Comparative data for fusion

Like many of the features of Kajkwakhrattxi, this nasality contrast for [r] is very rare crosslinguistically. It is, in fact, attested in only a handful of languages in India and Pakistan: Juang, Kangri, Waneci, Central and Northern Pashto (Moran \& McCloy 2019), and is otherwise unattested for Jê and Amazonian languages. The specific sound changes that gave rise to contrastively nasalized retroflexed rhotic consonants in these languages is, to the best of our knowledge, not known, but we suspect that they followed a similar diachronic trajectory as is proposed here for Kajkwakhrattxi.

3.5. GLIDING. All bilabial stops in Kajkwakhrattxi underwent a generalized process of gliding in syllable onset position. This sound change affected all oral stops, namely PNJ *p and *b for both languages within the Suyá clade, Kajkwakhrattxi and Kĩsêdjê. After the split between these two languages, the bilabial gliding process was extended to the nasal stops *m and * $\widehat{m b}$ in Kajkwakhrattxi. It is very likely that this sound change happened gradually over time, being telescoped through an intermediate fricative stage, though we do not have any direct record of this hypothesized spirantization process. As a result of this gliding process, bilabial stops [p $\left.\mathrm{p}^{\urcorner}, \mathrm{m}^{\urcorner}\right]$are now only attested in syllable codas word-internally, as allophones of $/ \mathrm{M} /$ and $/ \tilde{\mathrm{w}} /$, respectively. This gliding process produced two distinct sets of labial approximants: the labio-velar set [w, $\widetilde{\mathrm{w} W}, \tilde{\mathrm{w}}, \Lambda]$ before central and back vowels, and the labio-palatal set $[\mathrm{\Psi}, \widetilde{\tilde{\mathrm{u}}}, \tilde{\mathrm{u}}, \stackrel{\circ}{\mathrm{u}}]$ before front vowels $[i, e, \varepsilon]$. The details of the gliding process are summarized in (7).

$$
\begin{aligned}
& * \text { bilabial stop }>\text { (fricative) }>\text { glide } \\
& \text { a. } * \mathrm{p}>(\phi)>\mathrm{M} /{ }_{-} \mathrm{V} \\
& >\stackrel{\circ}{\mathrm{q}} / \text { _ front } \mathrm{V} \\
& \text { b. } * \mathrm{~b}>(\beta)>\mathrm{w} /{ }_{-} \mathrm{V} \\
& >\mathrm{u} / \text { _ front } \mathrm{V}
\end{aligned}
$$




$$
\begin{aligned}
& \text { c. } *_{\mathrm{m}}>(\tilde{\beta})>\tilde{\mathrm{w}} / \tilde{\mathrm{V}} \\
& \text { d. } \quad * \widehat{\mathrm{mb}}>(\tilde{\tilde{\beta}} \beta)>\tilde{\tilde{\mathrm{w}}} / \mathrm{\tilde {H }} / \mathrm{V} \\
& >\widetilde{\tilde{\mathrm{U}} \mathrm{U}} \text { /_front } \mathrm{V}
\end{aligned}
$$

As a synchronic process currently observed in Kajkwakhrattxi, labial approximants exhibit allophony between labio-velar and labio-palatal realizations, as in (8). Labio-velars (e.g. [w]) surface before central and back vowels, as well as before other approximants; and labio-palatals (e.g. $[\mathrm{Y}])$ surface before front vowels. Alternations of this type are reconstructible to PNJ, as this synchronic process is widely attested in languages of the family, including Xavante, Kajkwakhrattxi, and Panãra (Lapierre et al. 2016). As such, it is probably the case that bilabial stops underwent gliding and palatalization simultaneously before front vowels, rather than through an intermediate labio-velar step.

\section{(8) $/ \mathrm{w} / \rightarrow[\mathrm{\Psi}] /{ }_{-}$front $\mathrm{V}$}

Table 7 contains examples of gliding for PNJ *p, *b, *m, * ${ }^{\mathrm{mb}}$. PNJ *p corresponds to Kajkwakhrattxi voiceless $[M]$ in word-initial position $(a-c)$. PNJ *b corresponds to Kajkwakhrattxi [w] in syllable-initial position (d) as well as in word-initial position (e-f). PNJ *m corresponds to

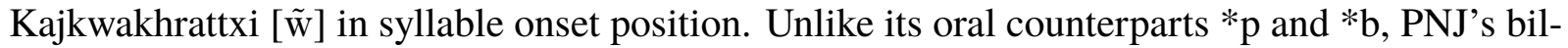
abial nasal *m occurs in word-final position ( $\mathrm{g}-\mathrm{i})$ and surfaces as unreleased when it immediately

\begin{tabular}{|c|c|c|c|c|c|c|}
\hline & Gloss & PNJ & Panãra & Kayapô & \multicolumn{2}{|c|}{ Kajkwakhrattxi } \\
\hline a. & 'arm' & $*$ pa & [pa] & [pa] & /ma/ & [Ma] \\
\hline b. & 'foot' & *par & {$[\mathrm{par}]$} & ['pai.ri] & /мај/ & [Maj] \\
\hline c. & 'achiote' & *pu & [pu] & [pu] & /MU/ & {$[M U]$} \\
\hline d. & 'brown howler' & *ku.'bus.du & [ip.'pur.ti] & [ku.'but'] & /knwut/ & 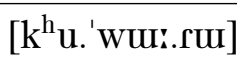 \\
\hline e. & 'to grab' & *bu & ['pus.ri] & [ha.'bu] & /kuww/ & [ku.'wu] \\
\hline f. & 'corn' & $* \mathrm{~b} \Lambda . ' \mathrm{t} \int \mathrm{u}$ & [mõ.'su] & [b么.'u] & /wntw/ & [ws.'tu] \\
\hline g. & 'smoke' & *kũm? & [sr.'kõy] & [kũm?] & $/ \mathrm{k}^{\mathrm{h}} \tilde{\mathrm{u}} \tilde{\mathrm{w}} /$ & {$\left[{ }^{\prime} \mathrm{k}^{\mathrm{h}} \tilde{\mathrm{u}} \mathrm{i} \cdot \tilde{\mathrm{w}} \tilde{\mathrm{u}}\right]$} \\
\hline h. & 'capybara' & *ku.'ndum? & [ĩn.'tup] & [ku.'nũm?] & $/ \mathrm{k}^{\mathrm{h}} \mathrm{ot}{ }^{\mathrm{h}} \tilde{\mathrm{u}} \tilde{\mathrm{w}} /$ & {$\left[\mathrm{k}^{\mathrm{h}} \mathrm{O} \cdot{ }^{\prime} \mathrm{t}^{\mathrm{h}} \tilde{\mathrm{u}}_{\mathrm{u}} \cdot \tilde{\mathrm{w}} \tilde{\mathrm{u}}\right]$} \\
\hline i. & 'to see' & *tكo.'mũ & [srm.'pũy] & [ho.'mũ] & /tõ w̃ũ/ & 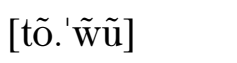 \\
\hline J. & 'tail' & *ţa.' $\widehat{m b u}$ & [sam.'pu] & [ha.'mu] & /taw̃u/ & [ta.' $\tilde{\text { wwwu] }}$ \\
\hline $\mathrm{k}$. & 'sun' & *'mbur.du & [ĩm.'pur.ti] & [mut'] & 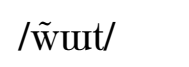 & 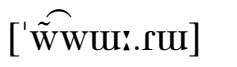 \\
\hline 1. & 'liver' & $*$ mba & [ĩm.'pa] & {$[\mathrm{ma}]$} & / $\tilde{\mathrm{w}} \mathrm{a} /$ & 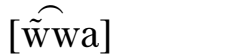 \\
\hline
\end{tabular}

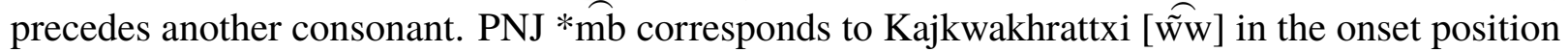
of a syllable $(\mathrm{j}-1)$.

Table 7. Comparative data for gliding 
Table 8 contains instances of labio-palatal glides in Kajkwakhrattxi, all occurring before front vowels. PNJ *p corresponds to Kajkwakhrattxi voiceless [ $\stackrel{\mathrm{U}}{\mathrm{C}}]$ in word-initial position (a). PNJ *b corresponds to Kajkwakhrattxi $[\mathrm{y}]$ in syllable-initial position (b) as well as word-initial position (c). PNJ *m corresponds to Kajkwakhrattxi [ $\tilde{\mathrm{u}}]$ in word-initial position (d). Finally, PNJ post-oralized $* \widehat{\mathrm{mb}}$ corresponds to Kajkwakhrattxi post-oralized [ $\widetilde{\mathrm{U}} \mathrm{\Psi}]$ in word-initial position (e).

\begin{tabular}{|c|c|c|c|c|c|}
\hline & Gloss & PNJ & Panãra & Kayapô & Kajkwakhrattxi \\
\hline a. & 'firewood' & *pĩ.'ๆgg & [pĩ] & 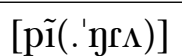 & 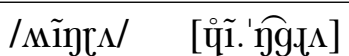 \\
\hline h & 'fish' & *'ter.be & ['te:.pi] & $[\mathrm{tep}\urcorner]$ & ['th $\left.{ }^{\mathrm{h}}: \mathrm{u} \varepsilon\right]$ \\
\hline c. & 'to scratch' & *bej & [nõ.'pen] & [ku.'be] & 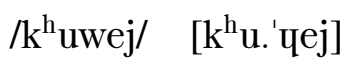 \\
\hline d. & 'alligator' & $*_{\mathrm{m}} \tilde{\mathrm{i}}$ & [mĩ] & [mĩ] & 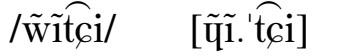 \\
\hline e. & 'honey' & *mbej & [nãm.'pen] & [mei] & 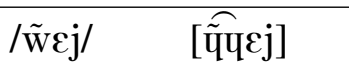 \\
\hline
\end{tabular}

Table 8. Comparative data for palatalization

Gliding is a widely attested lenition process (Blevins 2004). To the best of our knowledge, however, there does not exist another example of the specific diachronic change involving postoralized $* \widehat{m b}>(\tilde{\hat{\beta}} \beta)>\{\tilde{\mathrm{w} w}, \widetilde{\tilde{\mathrm{u}}}\}$, making this change unique to Kajkwakhrattxi. PNJ, like many of its daughter languages, exhibits a series of post-oralized allophones of its nasal consonants before contrastively oral vowels (e.g. $/ \mathrm{m} / \rightarrow[\widehat{\mathrm{mb}}]_{-}$V). As such, the specific change from $*$ mb $>$ $(\tilde{\hat{\beta}} \beta)>\{\tilde{\tilde{\mathrm{w}} \mathrm{W}}, \widetilde{\tilde{\mathrm{U}} \mathrm{U}}\}$ is unsurprising, given a diachronic process of gliding which affected all bilabial stops.

Palatalization processes are widely attested cross-linguistically (Campbell 2013). The palatalization of consonants within Slavic is well documented (Lunt 1981), including in the case of Old Church Slavonic velars * $\mathrm{k}$ and $* \mathrm{~g}$ palatalizing before front vowels. Alternations whereby labiovelar /W/ is realized as labio-palatal [ $\mathrm{\Psi}]$ before front vowels are attested in languages of West Africa, such as Gwari, a Niger-Congo language of Nigeria (Hyman \& Magaji 1970); Akan, a Niger-Congo language of Ghana (Adomako 2015); and Bamileke-Fe'fe', a Bantu language of Cameroon (Hyman 1972).

3.6. Summary of changes. All of the sound changes in Table 9 are instances of assimilation or lenition. Note that the unconditioned retroflexion of $*_{f}$ occurred prior to the flapping of $* d$. As such, the flap [r] currently observed in Kajkwakhrattxi does not correspond to PNJ *r. PNJ *b, *d became approximants in Kajkwakhrattxi [w, c], and all other sound changes in Table 9 are not crucially ordered.

\begin{tabular}{|c|c|l|}
\hline \multirow{2}{*}{ Assimilation } & Retroflexion & $\begin{array}{l}*_{\mathrm{r}}>\mathrm{r} \\
{ }_{\mathrm{r}}>\mathrm{\tau} / \text { velars_ }\end{array}$ \\
\cline { 2 - 3 } & Fusion & $*_{\mathrm{m}}>(\mathrm{m} \tilde{\mathrm{l}})>\tilde{\mathrm{l}}$ \\
\hline \multirow{2}{*}{ Lenition } & Flapping & $*_{\text {voiced coronal }>\mathrm{r}}$ \\
\cline { 2 - 3 } & Gliding & $*$ bilabial stop $>$ glide \\
\hline
\end{tabular}

Table 9. Summary of sound changes 


\section{Broader Implications.}

4.1. Relevance to Phonological TyPology. Kajkwakhrattxi's typologically rare sound inventory provides evidence for the possible breadth of phonological complexity in natural languages. Kajkwakhrattxi exhibits a total of six contrastive approximants /w, $\tilde{\mathrm{w}}, \Lambda,[, \tilde{\mathrm{l}}, \mathrm{j} /$, four of which are attested in less than $6 \%$ of the world's languages (Moran \& McCloy 2019). These six contrastive

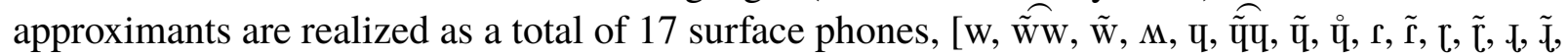
$\mathfrak{\imath}, j$, j], placing Kajkwakhrattxi among the world's languages with the densest inventories of approximants.

\begin{tabular}{|c|c|c|}
\hline Approximant & \# of Languages & \% of Languages \\
\hline W & 2483 & $82 \%$ \\
$\tilde{\mathrm{W}}$ & 18 & $<1 \%$ \\
$\mathrm{M}$ & 40 & $<1 \%$ \\
$\mathrm{I}$ & 179 & $6 \%$ \\
$\tilde{\mathrm{C}}$ & 10 & $<1 \%$ \\
$\mathrm{j}$ & 2716 & $90 \%$ \\
\hline
\end{tabular}

Table 10. Approximant frequency in the world's languages (Moran \& McCloy 2019)

One of the most distinctive characteristics of Kajkwakhrattxi's approximant inventory is the presence of a contrast in nasality for not only one, but two approximants, namely for both labial $/ \mathrm{w}, \tilde{\mathrm{w}} /$ and retroflex approximants $/ \mathrm{f}, \tilde{\mathrm{r}} /$. The existence of a contrastive retroflexed flap $/ \mathrm{r} /$ is itself very rare, as is the presence of a voiceless labio-velar $/ \mathrm{M} /$. In addition, the post-oralized nasal approximants [ $\tilde{\mathrm{w} w}, \widetilde{\mathrm{u}} \mathrm{U}]$, allophones of / $\tilde{\mathrm{w}} /$ before contrastively oral vowels, are previously undocumented.

As was argued in $\S 3$, this particularly dense inventory of approximants can be attributed to a series of natural sound changes involving lenition and assimilation from PNJ to Kajkwakhrattxi (see Table 9). Among other things, data from Kajkwakhrattxi reinforces well-known patterns in typology, such as palatalization before front vowels and flapping of [d]. In addition, our data provides evidence of sound changes that are, to best of our knowledge, unattested, such as the change from $*$ mb to $[\widehat{\widetilde{w}}, \widehat{\tilde{\mathrm{q}}}]$ ], involving a likely intermediate step of spirantization $[\widehat{\tilde{\beta}} \beta]$. It was argued that, while the specific outcome of this particular sound change is previously undocumented, it is motivated by the functional pressures that give rise to diachronic processes of consonant lenition cross-linguistically.

4.2. Relevance to Jê historical linguistics. Our reconstruction departs in significant ways from recent historical work touching on Kajkwakhrattxi approximants (Nikulin 2016, 2017,

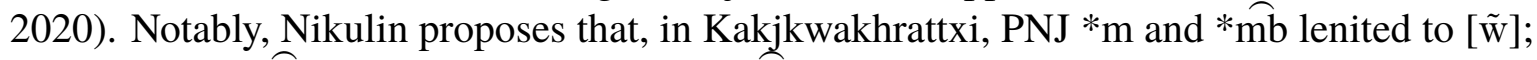
PNJ * mr and * mbr merged to [r]]; and PNJ * mbj simplified to [j]. Nikulin further proposes a sound change from PNJ * $>m$ in Proto-Suyá. This change was then followed by PNJ *b $>$ *p, reintroducing *p in the phonological inventory of Proto-Suyá, which then underwent * $p>$ w in Kajkwakhrattxi. Our work supports the proposal for a sound change from PNJ * $p>M$ in ProtoSuyá; however, our reconstruction differs in that we do not reintroduce *p to the inventory of Proto-Suyá, but rather propose a direct sound change from PNJ *b $>$ w, where PNJ *b was an allophone of PNJ *p in intervocalic position, in the onset of an unstressed syllable. In fact, we ar- 


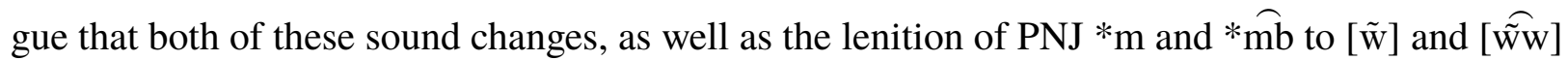
all happened as part of a single process of bilabial stop lenition (§3.5). It follows that only PNJ

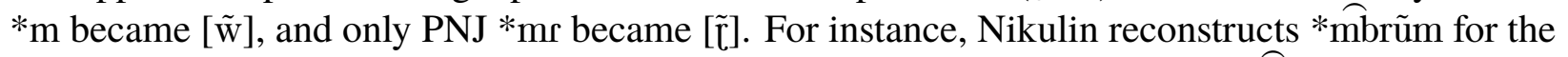
lexeme 'ant', whereas we reconstruct *mrũm?. The presence of post-oralized *mb is unlikely to result in nasal fusion, as post-oralization of the type $/ \mathrm{m} / \rightarrow[\widehat{\mathrm{mb}}]$ is a process that serves to prevent the spread of coarticulatory nasalization onto an immediately following segment (Herbert 1986; Stanton 2018; Wetzels \& Nevins 2018). Given that post-oralization and nasal fusion are two distinct mechanisms that result from opposite functional pressures (denasalization for the former, and nasalization for the latter), this motivates our analytical decision to reconstruct plain $* \mathrm{~m}$ rather than $*$ mb in $* m r$ clusters in PNJ.

Furthermore, Nikulin (2016) reconstructs a process of velar place assimilation affecting PNJ $*_{\mathrm{c}}$ after velar consonants, resulting in surface $[\chi]$ after $[\mathrm{k}]$ and surface $[\mathrm{s}]$ after [ $\left.\widehat{\mathrm{jg}}\right]$ and $[\mathrm{g}]$. With respect to the other rhotic consonants, the author also analyzes the alveolar flap [r] in Kajkwakhrattxi's synchronic phonological inventory as being derived from PNJ *s. Our work supports place assimilation affecting rhotic consonants after velar obstruents; however, we analyze this as a process of retroflexion rather than velarization, with slightly different phonetic realizations based on our use of distinct phonetic transcriptions. Furthermore, we propose that this unconditioned retroflexion process affected all of PNJ's alveolar consonants, namely $*_{\mathrm{r}}$ and $*_{\mathrm{t}}$, such that the current reflexes of these phonemes are $[\mathrm{r}]$ and $\left[\mathrm{t}^{\mathrm{h}}\right]$ respectively. We crucially analyze the alveolar flap currently observed in Kajkwakhrattxi as arising from PNJ *d, which synchronically patterns as an allophone of /t/ in intervocalic position in the onset of an unstressed syllable. We additionally propose a process of nasal assimilation affecting Kajkwakhrattxi's retroflexed ap-

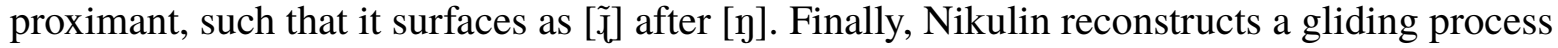
whereby PNJ *n > j in coda position for Kajkwakhrattxi. While this hypothesis may be true, we do not, at this time, find any clear evidence in support of the proposal that this was a regularly occurring sound change from PNJ to Kajkwakhrattxi.

With the use of our novel fieldwork data from Kajkwakhrattxi, Panãra, and Kayapô, we produce a more detailed and internally consistent comparative analysis of Northern Jê, from which we posit the reconstructed PNJ forms in Tables 4 through 8. It is important to note that Kajkwakhrattxi and Panãra are the two most divergent and underdescribed Northern Jê languages, making the inclusion of this data crucial to producing a better informed historical reconstruction. Prior to this work, some reconstructions did not make use of any Kajkwakhrattxi data at all (Davis 1966). In the case of Nikulin (2020) and Lapierre et al. (2016), the authors made use of Camargo's (2010; 2015) descriptions of Kajkwakhrattxi, which did not include the level of phonetic detail present in Beauchamp \& Lapierre's data. These earlier descriptions do not transcribe the presence of either nasality or palatalization in approximants, resulting in the following phones

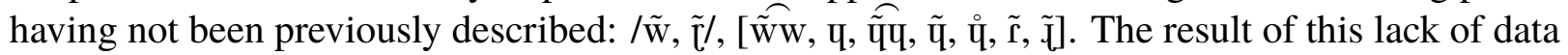
is that fusion (\$3.4) and palatalization could not be properly reconstructed using previously available data. The same is true for some of the specific outcomes of the retroflexion (\$3.2), flapping (§3.3), and gliding $(\$ 3.5)$ processes.

The work presented in this article provides a clear example of the importance of producing detailed phonetic transcriptions in documenting under-described languages, such as Kajkwakhrattxi, Panãra, and Kayapô. The inclusion of our novel fieldwork data advances the current understanding of the sound system of PNJ and the diachronic processes that gave rise to the sound systems of its daughter languages. 


\section{References}

Adomako, Kwasi. 2015. Some phonological processes in an Akan linguistic game. Linguistik Online 72(3). https://doi.org/10.13092/lo.72.1970.

Albany, Katie. 2015. /n:/r/correspondences in Albanian dialects: Understanding the $n>r$ sound change. New York: City University of New York MA thesis.

Alves, Flávia de Castro. 2004. O timbira falado pelos canela apãniekrá: uma contribuição aos estudos da morfossintaxe de uma língua jê. Campinas: Universidade Estadual de Campinas dissertation.

Amado, Rosane de Sá. 2004. Aspectos morfofonológicos do gavião-pykobjê. São Paulo: Universidade de São Paulo dissertation.

de Aquino, Pe Thomaz. 1970. Carta de Pe Thomaz para Pe Balduino. Lisbon, Portugal.

Bakst, Sarah. 2012. Rhotics and retroflexes in Indic and Dravidian. Cambridge: University of Cambridge MA thesis.

Beauchamp, Jérémie, Myriam Lapierre, Nokêrê Tapayuna \& Orengô Tapayuna. 2020. Kajkwakhrattxi fieldwork materials. University of California, Berkeley: Survey of California and Other Indian Languages. https://doi.org/doi:10.7297/X2RF5SH0.

Beauchamp, Jérémie. 2019. Aspects of a revised phonological description of Kajkwakhrattxi (Jê). Talk presented at the 2019 Symposium on Amazonian Languages. University of California, Berkeley.

Blevins, Juliette. 2004. Evolutionary phonology: The emergence of sound patterns. Cambridge: Cambridge University Press.

Camargo, Nayara da Silva. 2010. Lingua tapayúna: aspéctos sociolinguísticos e uma análise fonológica preliminar. Campinas: Universidade Estadual de Campinas MA thesis.

Camargo, Nayara da Silva. 2015. Tapayuna (jê): aspectos morfossintáticos, históricos e sociolinguísticos. Campinas: Universidade Estadual de Campinas dissertation.

Campbell, Lyle. 2013. Historical linguistics. An introduction. Edinburgh: Edinburgh University Press.

Davis, Irvine. 1966. Comparative Jê Phonology. Estudos Lingüísticos: Revista Brasileira de Lingüística Teórica e Aplicada 1. 10-24.

Hamann, Silke. 2005. The diachronic emergence of retroflex segments in three languages. Link 15(1). 29-48.

Herbert, Robert. 1986. Language universals, markedness theory, and natural phonetic processes. Berlin: De Gruyter Mouton.

Hyman, Larry Michael. 1972. A phonological study of Fe'fe'-Bamileke. Los Angeles: University of California dissertation.

Hyman, Larry Michael \& Daniel Magaji. 1970. Essentials of Gwari grammar. Ibadan, NG: Ibadan University Press.

Lapierre, Myriam, Bernat Bardagil-Mas \& Andrés Salanova. 2016. A reconstruction of ProtoNorthern Jê phonemics. Talk presented at Amazônicas VI. Universidad Nacional de Colombia, Leticia.

Lapierre, Myriam \& Teela Huff. Ms. A phonological reconstruction of Proto-Northern-Jê. Unpublished manuscript, University of California, Berkeley. 
Lapierre, Myriam, Sôpôa Panära, Sokkrëë Panära \& Saankôrä Panära. 2020. Panãra fieldwork materials. University of California, Berkeley: Survey of California and Other Indian Languages. https://doi.org/doi:10.7297/X20R9MWN .

Lima, Daniela Batista de. 2019. A história do contato e o desterro tapayuna: um massacre anunciado. Brasília: Universidade de Brasília dissertation.

Lipski, John M. 2011. Socio-phonological variation in Latin American Spanish. In Manuel Díaz-Campos (eds.), The handbook of Hispanic sociolinguistics 72-96. Hoboken, NJ: Wiley. https://doi.org/10.1002/9781444393446.ch4 .

Lunt, Horace Gray. 1981. The progressive palatalization of common slavic. Skopje, MK: Macedonian Academy of Sciences and Art.

Mielke, Jeff, Adam Baker \& Diana Archangeli. 2016. Individual-level contact limits phonological complexity: Evidence from bunched and retroflex/.t. Language 92(1). 101-140. https://doi.org/10.1353/lan.2016.0019.

Miranda, Maxwell Gomes. 2010. As nominalizações na sintaxe da língua krahô (jê). Brasília: Universidade de Brasília MA thesis.

Moran, Steven \& Daniel McCloy (eds.). 2019. Phoible 2.0. Jena: Max Planck Institute for the Science of Human History. https://phoible.org/.

Nikulin, Andrey. 2016. Historical phonology of Proto-Northern Jê. Journal of Language Relationship 14(3). 165-185. https://doi.org/10.31826/jlr-2017-143-405.

Nikulin, Andrey. 2017. A phonological reconstruction of Proto-Cerrado (Jê family). Journal of Language Relationship 15(3). 147-180. https://doi.org/10.31826/jlr-2018-153-404.

Nikulin, Andrey. 2020. Proto-Macro-Jê: Um estudo reconstrutivo. Brasília: Universidade de Brasília dissertation.

Nonato, Rafael. 2014. Clause chaining, switch reference and coordination. Cambridge, MA: MIT dissertation.

Oliveira, Christiane Cunha de. 2005. The language of the Apinajé people of central Brazil. Eugene, OR: University of Oregon dissertation.

Popjes, Jack \& Josephine Popjes. 1986. Canela-krahô. In Desmond C. Derbyshire \& Geoffrey K. Pullum (eds.), The handbook of Amazonian languages, 128-199. Berlin: Mouton de Gruyter.

Rodrigues, Cíntia Karla Coelho \& Marília de Nazaré Ferreira-Silva. 2011. Comparando as consoantes das línguas tapajúna e suyá. Alfa: Revista de Linguística 55(2). 601-611.

Santos, Ludoviko Carnasciali dos. 1997. Descrição de aspectos morfossintáticos da língua suyá (kisêdjê) família jê. Florianópolis: Universidade Federal de Santa Catarina dissertation.

Silva, Talita Rodrigues da. 2011. Descrição e análise morfossintática do nome e do verbo em pykobjê-gavião (timbira). São Paulo: Universidade de São Paulo MA thesis.

Souza, Sueli Maria de. 2011. O sistema de referencia da língua krahô. Goiânia: Universidade Federal de Goiás MA thesis.

Stanton, Juliet. 2018. Environmental shielding is contrast preservation. Phonology 35(1). 39-78. https://doi.org/10.1017/S0952675717000379.

Wetzels, W Leo \& Andrew Nevins. 2018. Prenasalized and postoralized consonants: The diverse functions of enhancement. Language 94(4). 834-866. https://doi.org/10.1353/lan.2018.0075. 